\title{
ANALISIS PENGENDALIAN KUALITAS PRODUK PAKAN TERNAK DENGAN METODE STATISTICAL QUALITY CONTROL (SQC) PADA PERUSAHAAN PAKAN TERNAK DI KARAWANG
}

\author{
Muhamad sayuti, \\ email muhamad.sayuti@ubpkarawang.ac.id
}

\begin{abstract}
ABSTRAK
Kegiatan pengendalian kualitas tersebut dapat dilakukan mulai dari bahan baku, selama proses produksi berlangsung sampai pada produk akhir dan disesuaikan dengan standar yang telah ditetapkan dan diberlakukan oleh perusahaan. Pengendalian kualitas penting dilaksanakan, tidak hanya untuk usaha berkapasitas ekspor maupun usaha-usaha kecil, begitu pula perusahaan $X$ di Karawang. Perusahaan Pakan Ternak Unit Karawang menyediakan sumber protein hewani melalui pakan ternak bermutu dan bertekad menjadi market leader di wilayah Jawa, dengan semangat "Tumbuh dan berkembang menuju kesejahteraan bersama" Dalam mewujudkan tekad tersebut Perusahaan Pakan Ternak Unit Karawang menerapkan "Sistem Manajemen Mutu ISO 9001:2008" dengan melakukan perbaikan terus menerus yang mengacu pada persyaratan peraturan dan perundang-undangan yang berlaku di Indonesia. Namun dalam proses produksi, tidak selamanya produk pakan ternak berhasil 100\%. Hasil produksi perhari yaitu $28.000 \mathrm{~kg}$ dan yang mengalami kerusakan yaitu sekitar 7 karung. Standar kerusakan yang ditetapkan perusahaan yaitu berkisar dari 0,1 \% - 1\%. Karena produk yang dihasilkan beragam sehingga pengendalian kualitas dirasakan sangat penting, maka penulis tertarik untuk melakukan penelitian mengenai pengendalian kualitas produk pakan ternak Pada Perusahaan Pakan Ternak
\end{abstract}

Kata Kunci : Produk cacat, Pengendalian Kualitas, Standar Kerusakan Produk

\section{Pendahuluan}

Dewasa ini perkembangan perekonomian Indonesia berada pada tingkat pertumbuhan yang kurang menggembirakan. Hal ini merupakan dampak dari adanya resesi perekonomian yang tak kunjung habis. Dunia usaha dituntut untuk dapat bertahan hidup walaupun harus mengalami berbagai krisis yang dimulai dengan krisis moneter, krisis ekonomi yang berakhir dengan krisis multidimensional.

Kegiatan pengendalian kualitas tersebut dapat dilakukan mulai dari bahan baku, selama proses produksi berlangsung sampai pada produk akhir dan disesuaikan dengan standar yang telah ditetapkan dan diberlakukan oleh perusahaan. Pengendalian kualitas penting dilaksanakan, tidak hanya untuk usaha berkapasitas ekspor maupun usaha-usaha kecil, begitu pula perusahaan X di Karawang. Unit Karawang adalah salah satu pabrik pakan ternak yang secara langsung akan 
bersentuhan dengan teknologi modern dan juga tegangan listrik yang berbahaya. Perusahaan Pakan Ternak Unit Karawang menyediakan sumber protein hewani melalui pakan ternak bermutu dan bertekad menjadi market leader di wilayah Jawa, dengan semangat "Tumbuh dan berkembang menuju kesejahteraan bersama" Dalam mewujudkan tekad tersebut Perusahaan Pakan Ternak Unit Karawang menerapkan "Sistem Manajemen Mutu ISO 9001:2008" dengan melakukan perbaikan terus menerus yang mengacu pada persyaratan peraturan dan perundang-undangan yang berlaku di Indonesia.

Namun dalam proses produksi, tidak selamanya produk pakan ternak berhasil $100 \%$. Hal ini dikarenakan ketidakseragaman produk yang dihasilkan,mulai Packaging yang rusak yaitu sobek, ukuran butiran yang tidak seragam, pewarnaan yang tidak seragam dan kadar campuran yang tidak sama pada setiap produksi ini mengakibatkan kualitas produk menurun, sehingga diperlukan pengendalian kualitas untuk meminimalisir masalah produk. Hasil produksi perhari yaitu $28.000 \mathrm{~kg}$ dan yang mengalami kerusakan yaitu sekitar 7 karung. Standar kerusakan yang ditetapkan perusahaan yaitu berkisar dari $0,1 \%-1 \%$.

Karena produk yang dihasilkan beragam sehingga pengendalian kualitas dirasakan sangat penting, maka penulis tertarik untuk melakukan penelitian mengenai pengendalian kualitas produk pakan ternak Pada Perusahaan Pakan Ternak. Unit Karawang dengan mengangkat judul Analisis Pengendalian Kualitas Produk Pakan Ternak dengan metode Statistical Quality Control (SQC) Pada Perusahaan Pakan Ternak di Karawang.

\section{Perumusan Masalah}

Berdasarkan uraian latar belakang di atas, maka rumusan masalahnya yaitu, sebagai berikut :

1. Bagaimana mengetahui kecacatan yang terjadi pada produk pakan ternak di Karawang.

2. Bagaimana penerapan Statistical Quality Control (SQC) dalam mengendalikan kualitas produk pakan ternak pada Perusahaan Pakan ternak di Karawang.

\section{Tujuan Penelitian}

Sesuai dengan masalah penelitian yang diuraikan di atas, maka tujuan penelitian ini adalah sebagai berikut :

1. Untuk mengetahui kecacatan yang terjadi pada produk pakan ternak di Perusahaan Pakan Ternak Karawang

2. Untuk mengetahui penerapan Statistical Quality Control (SQC) dalam mengendalikan kualitas produk pakan ternak Pada Perusahaan Pakan ternak di Karawang.

\section{Alat Bantu Pengendalian Kualitas}

Dalam melakukan kegiatan pengendalian kualitas terdapat teknik atau alat pengendalian kualitas yang dapat digunakan mengidentifikasikan dan menganalisis masalah-masalah kualitas yang sedang dihadapi agar masalah-masalah tersebut dapat dikendalikan. 
Menurut Montgomery (2001:154) terdapat 7 (tujuh) alat bantu untuk mengendalikan kualitas, yaitu :

1. Process flow chart

Gambar yang menjelaskan langkah-langkah utama, cabang-cabang proses dan produk akhir dari proses.

2. Pareto analysis

Pendekatan yang terkoordinasi untuk mengidentifikasikan, mengurutkan dan bekerja untuk menyisihkan ketidaksesuaian secara permanen. Memfokuskan pada sumber kesalahan yang penting. Aturannya 80/20 yaitu $80 \%$ dari masalah dan $20 \%$ adalah penyebabnya,

3. Histogram

Distribusi yang menunjukkan frekuensi kejadian-kejadian di antara jajaran data yang tinggi dan rendah.

4. Scatter diagram

Dikenal juga dengan peta korelasi. Grafik dari nilai suatu karakteristik yang dibandingkan dengan nilai karakteristik yang lain.

5. Chek Sheet

Merupakan alat pengumpul dan penganalisis data, disajikan dalam bentuk tabel yang berisi nama dan jumlah barang yang diproduksi dan jenis ketidaksesuaian beserta jumlah yang dihasilkan.

6. Control Chart

Peta ukuran waktu yang menunjukkan nilai-nilai statistika, termasuk garis pusat dan satu atau lebih batas kendali yang didapat secara statistika

7. Cause and Effect Diagram

Alat yang menggunakan penggambaran secara grafik dari elemen-elemen proses untuk menganalisis sumber-sumber potensial dari variasi proses 


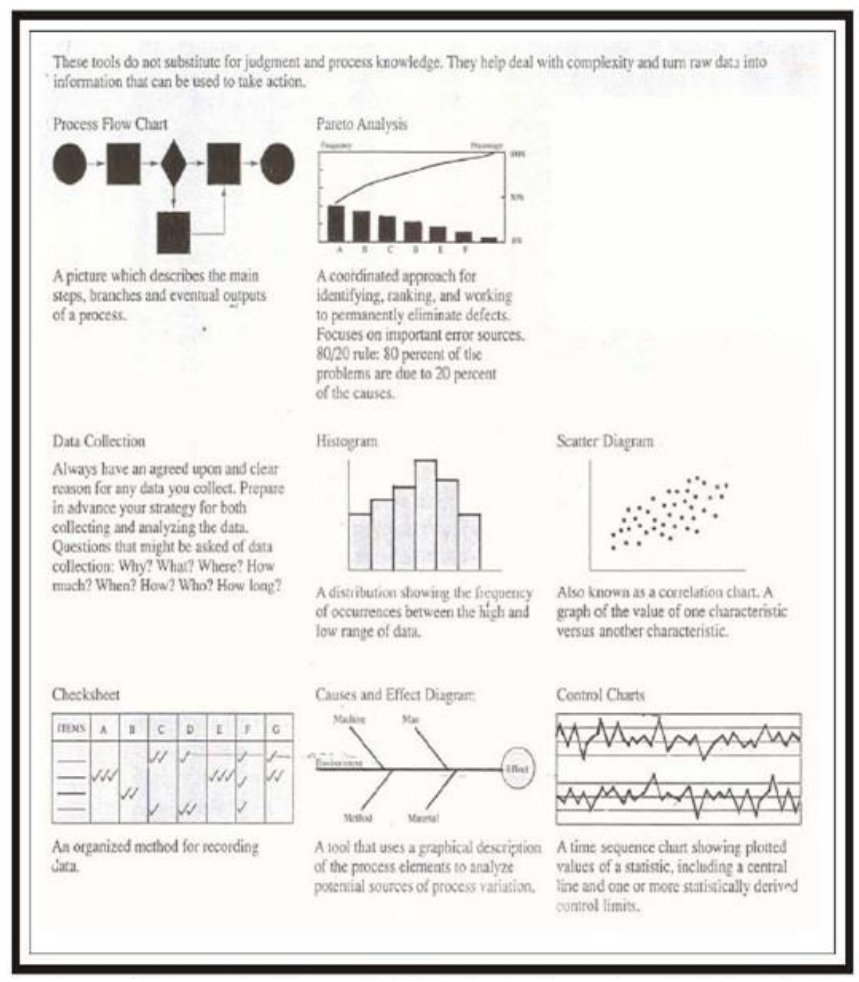

(Gambar 1 Alat Bantu Pengendalian Kualitas)

Menurut Kuswandi dan Mutiara (2004:41), terdapat 7 (tujuh) alat bantu untuk mengendalikan kualitas. Secara umum ketujuh alat tersebut memiliki kegunaan sebagai berikut :

1. Mengetahuui permasalahan apa yang sedang dihadapi

2. Mempersempit ruang lingkup perusahaan

3. Mencari faktor-faktor yang diperkirakan sebagai penyebab dari permasalahan

4. Memastikan bahwa faktor-faktor tersebut berhubungan dengan permasalahan

5. Mencegah kesalahan akibat kelalaian yang tidak perlu

6. Melihat hasil setelah perbaikan

7. Mengetahui penyimpangan yang terjadi

\section{Statistical Quality Control (SQC)}

Statistical Quality Control merupakan suatu kegiatan pengendalian kualitas terh adap bahan baku, proses produksi dan barang jadi untuk menjaga agar produk tetap pada standar kualitas yang telah ditetapkan. Sebelum membahas lebihjauh mengenai pengendalian kualitas secara statistika perlu dikemukakan terlebih dahulu mengenai pengertian pengendalian kualitas secara statistika.

Menurut Bestaei (2004:121) mengemukakan bahwa "proses pengendalian secara stastistik merupakan teknik statistik yang secara luas digunakan untuk memastikan bahwa proses yang sedang berjalan telah memenuhi standar". Sedangkan menurut Assauri (2004:219) mengemukakan bahwa pengertian dari SQC adalah suatu system yang dikembangkan untuk menjaga standar yang uniform dari kualitas hasil produksi, pada tingkat biaya yang minimum dan merupakan bantuan untuk mencapai efisiensi.

Dari defenisi di atas dapat ditarik kesimpulan bahwa Statistical Quality Control (SQC) adalah suatu alat pengendalian kualitas yang menggunakan metode statistika untuk 
mengumpulkan, menganalisis serta menginterpretasikan data untuk digunakan dalam kegiatan pengendalian kualitas ditinjau dari kesesuaian dengan spesifikasi yang telah ditetapkan.

\section{Peta kendali (control chart)}

Menurut Russell dan Taylor III (1998:134) peta kendali (control chart) didefenisikan sebagai grafik yang mencerminkan batas kendali suatu proses. Sedangkan menurut Besterfield (1994:29) adalah teknik yang dikenal untuk memecahkan masalah dan menghasilkan perbaikan kualitas.

Dari kedua defenisi diatas dapat disimpulkan bahwa peta kendali adalah teknik yang dikenal sebagai suatu metode grafik yang digunakan untuk mengevaluasi apakah suatu proses berada dalam pengendalian kualitas secara statistika atau tidak sehingga dapat memecahkan masalah dan menghasilkan perbaikan kualitas.

Peta kendali menunjukkan adanya perubahan data dari waktu ke waktu tetapi tidak menunjukkan penyebab penyimpangan meskipun penyimpangan itu akan terlihat pada peta kendali. Peta kendali merupakan grafik garis yang terdiri dari tiga buah garis mendatar sejajar yang terletak di dalam sebuah sumbu salib dan mencantumkan batas minimum dan batas maksimum yang berguna untuk memecahkan masalah yang terjadi dan menghasilkan perbaikan kualitas serta terdapat titik-titik yang menyebar diantara garis pembatas. Manfaat peta kendali adalah untuk :

1. Menentukan apakah suatu proses produksi masih berada di dalam batas-batas kendali atau tidak terkendali.

2. Memantau proses produksi secara terus menerus agar tetap stabil.

3. Menentukan kemampuan proses (capabilityprocess)

\section{Waktu dan Tempat Penelitian}

Waktu penelitian dilakukan selama dua bulan dengan lokasi penelitian Perusahaan pakan ternak di karawang

\section{Jenis dan Sumber Data}

Adapun jenis dan sumber data dalam penelitian ini diperoleh dari :

1. Data Primer yaitu data yang diperoleh dengan mengadakan observasi langsung dengan wawancara dengan pimpinan dan karyawan.

2. Data sekunder yaitu data yang diperoleh dari beberapa literatur, terutama yang berhubungan dengan permasalahan yang dijumpai dalam penelitian sebagai landasan teori sekaligus penunjang dalam penulisan.

\section{Metode Pengambilan Data}

Untuk mendapatkan hasil data yang diperlukan dalam menunjang penulisan ini, maka penulis memperoleh data dengan cara sebagai berikut :

a. Teknik observasi, yaitu dengan melakukan pengamatan langsung terhadap proses pembuatan pakan ternak dengan menggunakan analisa keadaan cacat. 
b. Teknik wawancara, yaitu melakukan tanya jawab langsung dengan pimpinan usaha dan karyawan.

\section{Hasil Produksi}

Tabel 1 Hasil Produksi Pada Perusahaan Pakan Ternak di Karawang Identifikasi Selama Tanggal 3 Mei s/d 15 Juni 2017

\begin{tabular}{|c|c|c|}
\hline No. & $\begin{array}{c}\text { Tanggal } \\
\text { (Juni 2013) }\end{array}$ & $\begin{array}{c}\text { Total Produksi } \\
\text { (Karung) }\end{array}$ \\
\hline 1 & 3 & 560 \\
\hline 2 & 5 & 570 \\
\hline 3 & 7 & 580 \\
\hline 4 & 10 & 560 \\
\hline 5 & 12 & 556 \\
\hline 6 & 14 & 600 \\
\hline 7 & 17 & 602 \\
\hline 8 & 19 & 566 \\
\hline 9 & 21 & 580 \\
\hline 10 & 24 & 560 \\
\hline & Jumlah & 5734 \\
\hline
\end{tabular}

Tabel 2 Data Jumlah Cacat Produksi Pada Perusahaan Pakan Ternak di Karawang

\begin{tabular}{|l|l|l||c|}
\hline No & Tanggal & Jenis Cacat & Total \\
\hline
\end{tabular}




\begin{tabular}{|c|c|c|c|c||}
\hline & (Juni 2013) & Karung Sobek & $\begin{array}{c}\text { Ketidakseragaman } \\
\text { warna }\end{array}$ & \\
\hline 1 & 3 & 3 & 2 & 5 \\
\hline 2 & 5 & 7 & 3 & 10 \\
\hline 3 & 7 & 8 & 6 & 14 \\
\hline 4 & 10 & 4 & 2 & 6 \\
\hline 5 & 12 & 0 & 5 & 5 \\
\hline 6 & 14 & 15 & 25 & 40 \\
\hline 7 & 17 & 7 & 9 & 16 \\
\hline 8 & 19 & 2 & 0 & 2 \\
\hline 9 & 21 & 18 & 5 & 37 \\
\hline 10 & 24 & 2 & 76 & 142 \\
\hline \hline & Jumlah & 66 & & \\
\hline
\end{tabular}

\section{Pengolahan Data}

PerhitunganPresentase Kecacatan

Tabel 3 Kecacatan Pakan Ternak Brider

\begin{tabular}{|c|c|}
\hline Jenis Cacat & $\begin{array}{c}\text { Jumlah Cacat } \\
\text { (Karung) }\end{array}$ \\
\hline Karung Sobek & 66 \\
\hline $\begin{array}{c}\text { Ketidakseragaman warna } \\
\text { (Hitam) }\end{array}$ & 76 \\
\hline
\end{tabular}

Dari tabel diatas, dilakukan perhitungan/analisa secara berurut berdasarkan frekuensi kejadian yang tertinggi sampai terendah, serta menghitung frekuensi kejadian komulatif, persentase dari total cacat dan total cacat dari komulatif. Adapun langkah-langkahnya adalah sebagai berikut :

Dari data diperoleh: $\quad$ - Ketidakseragaman warna (Hitam) $=76$

$$
\text { - Karung Sobek } \quad=66
$$

Maka diperoleh :

- Frekuensi kumulatif $=$ frekuensi tot cacat $1+$ frekuensi tot cacat 2

$$
\begin{aligned}
& =76+66 \\
& =142 \text { Karung }
\end{aligned}
$$

- \% dari total cacat ketidakseragaman warna 


$$
\begin{aligned}
& =\frac{\text { frekuensi cacat }}{\text { total frekuensi }} \times 100 \% \\
& =\frac{76}{142} \times 100 \% \\
& =0,54 \times 100 \% \\
& =54 \%
\end{aligned}
$$

- \% dari total cacat Karung Sobek

$$
\begin{aligned}
& =\frac{\text { frekuensicacat }}{\text { totalfrekuensi }} \times 100 \% \\
& =\frac{66}{142} \times 100 \% \\
& =0,46 \times 100 \% \\
& =46 \%
\end{aligned}
$$

Tabel 4 Data Olahan Jumlah Frekuensi Total Cacat Produk Pakan Ternak

\begin{tabular}{|c|c|c|c|c|}
\hline Urutan jenis cacat & $\begin{array}{c}\text { Frekuensi } \\
\text { Cacat } \\
\text { (Karung) }\end{array}$ & $\begin{array}{c}\text { Frekuensi } \\
\text { Kumulatif } \\
\text { (Karung) }\end{array}$ & $\begin{array}{c}\text { Persen } \\
\text { Cacat } \\
(\boldsymbol{\%})\end{array}$ & $\begin{array}{c}\text { Persen } \\
\text { Kumulatif } \\
(\boldsymbol{\%})\end{array}$ \\
\hline Ketidakseragaman warna & 76 & 66 & 54 & 46 \\
\hline Karung Sobek & 66 & 142 & 46 & 100 \\
\hline & 142 & & 100 & \\
\hline
\end{tabular}

Berdasarkan hasil perhitungan diatas maka perioritas tindakan perbaikan untuk masalah cacat produk pakan ternak briderdiperoleh :

1. Ketidakseragaman warna (hitam) = Prioritas cacat $54 \%$

2. Karung Sobek

$=$ Prioritas cacat $46 \%$

\section{Pengolahan Dengan Control Chart $(\mathbf{P})$}

Tabel 6 Populasi Data Dapat Dibuatkan Grafik Pengendali Dengan Control Chart Adalah Sebagai Berikut :

\begin{tabular}{|c|c|c|c|c|}
\hline No. & $\begin{array}{c}\text { Tanggal } \\
\text { (Juni 2013) }\end{array}$ & $\begin{array}{c}\text { Jumlah Frekuensi } \\
\text { (Karung) }\end{array}$ & $\begin{array}{c}\text { Proporsi } \\
\text { Cacat }\end{array}$ & $\begin{array}{c}\text { Presentase } \\
\text { Cacat } \\
(\%)\end{array}$ \\
\hline 1 & 3 & 5 & 0.008929 & 0.892857 \\
\hline 2 & 5 & 10 & 0.017544 & 1.754386 \\
\hline 3 & 7 & 14 & 0.024138 & 2.413793 \\
\hline 4 & 10 & 6 & 0.010714 & 1.071429 \\
\hline 5 & 12 & 5 & 0.008993 & 0.899281 \\
\hline 6 & 14 & 40 & 0.066667 & 6.666667 \\
\hline 7 & 17 & 16 & 0.026578 & 2.657807 \\
\hline 8 & 19 & 2 & 0.003534 & 0.353357 \\
\hline 9 & 21 & 37 & 0.063793 & 6.37931 \\
\hline
\end{tabular}




\begin{tabular}{|c|c|c|c|c|}
\hline 10 & 24 & 7 & 0.0125 & 1.25 \\
\hline & Jumlah & $\mathbf{1 4 2}$ & $\mathbf{0 . 2 4 3 3 8 9}$ & $\mathbf{2 4 . 3 3 8 8 9}$ \\
\hline & Rata-rata & $\mathbf{1 4 . 2}$ & $\mathbf{0 . 0 2 4 3 3 9}$ & $\mathbf{2 . 4 3 3 8 8 9}$ \\
\hline
\end{tabular}

Berdasarkan data dari hasil perhitungan dalam tabel 4.6, kita akan menghitung simpangan baku untuk peta control $\mathrm{P}$, yaitu :

- Apabila menggunakan nilai proporsi simpangan baku dihitung sebagai berikut :

$$
\begin{aligned}
& \mathrm{sp}=\sqrt{\frac{p(1-p)}{n}} \\
& \mathrm{sp}=\sqrt{\frac{0.024339(1-0.024339)}{142}} \\
& \mathrm{sp}=\sqrt{\frac{0.024339(0,975661)}{142}} \\
& \mathrm{sp}=\sqrt{0,000167} \\
& \mathrm{sp}=0,0129
\end{aligned}
$$

- Dan apabila kita menggunakan persentase, maka simpangan baku dihitung sebagai berikut :

$$
\begin{aligned}
& \mathrm{sp}=\sqrt{\frac{p(100-p)}{n}} \\
& \mathrm{sp}=\sqrt{\frac{2.433889(100-2.433889)}{142}} \\
& \mathrm{sp}=\sqrt{\frac{2.433889(97.5661)}{142}} \\
& \mathrm{sp}=\sqrt{1,672289} \\
& \mathrm{sp}=1,29 \%
\end{aligned}
$$

Selanjutnya menentukan batas-batas control 3-sigma sebagai berikut :

- Peta control (batas-batas control 3-sigma) untuk nilai proporsi:

$$
\begin{aligned}
C L & =\bar{P}=0.024339 \\
\mathrm{UCL} & =\bar{P}+3 . \mathrm{sp} \\
& =0.024339+3(0,0129) \\
& =0,062889 \\
\mathrm{LCL} & =\bar{P}-3 . \mathrm{sp} \\
=0.024339-3 & (0,0129) \\
& =-0,01442
\end{aligned}
$$

- Peta control P (batas-batas control 3-sigma) untuk menilai persentase : CL $=\bar{P}=2,43 \%$ 


$$
\begin{aligned}
\mathrm{UCL} & =\bar{P}+3 . \mathrm{sp} \\
& =2,43 \%+3(1,29 \%) \\
& =2,43 \%+3,87 \% \\
& =6,3 \% \\
\mathrm{LCL} & =\bar{P}-3 . \mathrm{sp} \\
& =2,43 \%-3(1,29 \%) \\
& =2,43 \%-3,87 \% \\
& =-1,44 \%
\end{aligned}
$$

- Pengolahan dengan indeks kapasitas $(\mathrm{Cp})$

Pengolahan ini digunakan untuk mengetahui kapabilitas suatu produk apakah produk itu baik atau jelek. Dari analisa perhitungan peta control P maka didapatkan Cp sebagai berikut :

Indeks kapasitas proses $(\mathrm{Cp})$ pada peta control untuk nilai proporsi :

$$
\mathrm{Cp}=\frac{U C L-L C L}{6.5} \rightarrow \mathrm{s}=1-\mathrm{P}
$$

Dimana: $\mathrm{Cp}=$ indeks kapasitas

$\mathrm{P} \quad=$ rata-rata kecacatan

$\mathrm{UCL}=$ garis kendali atas

$\mathrm{LCL}=$ garis kendali bawah

6.s = enam simpangan baku

Jadi :

$$
\begin{aligned}
\mathrm{Cp} & =\frac{0,062889-(-0,01442)}{6(0,975661)} \\
& =\frac{0,077309}{5,853966} \\
& =0,0132
\end{aligned}
$$

Indeks kapasitas proses $(\mathrm{Cp})$ pada peta control untuk nilai persentase :

$$
\begin{aligned}
\mathrm{Cp} & =\frac{U C L-L C L}{6 . S} \rightarrow \mathrm{s}=100 \%-\mathrm{P} \\
\mathrm{Cp} & =\frac{6,3 \%-(-1,44 \%)}{6(97,56 \%)} \\
& =\frac{7,74 \%}{585,36 \%} \\
& =0,0132 \%
\end{aligned}
$$

\section{Pengolahan Dengan Diagram Sebab Akibat (Fish Bone)}

Adapun faktor-faktor yang kita tinjau adalah sebagai berikut :

1. Manusia (man)

2. Metode kerja (work method)

3. Mesin

4. Bahan baku

5. Lingkungan kerja 
Dari lima faktor diatas dipelajari faktor-faktor yang paling berpengaruh terhadap permasalahan yang akan dihadapi. Faktor-faktor yang berpengaruh sehingga terjadi kecacatan produk adalah:

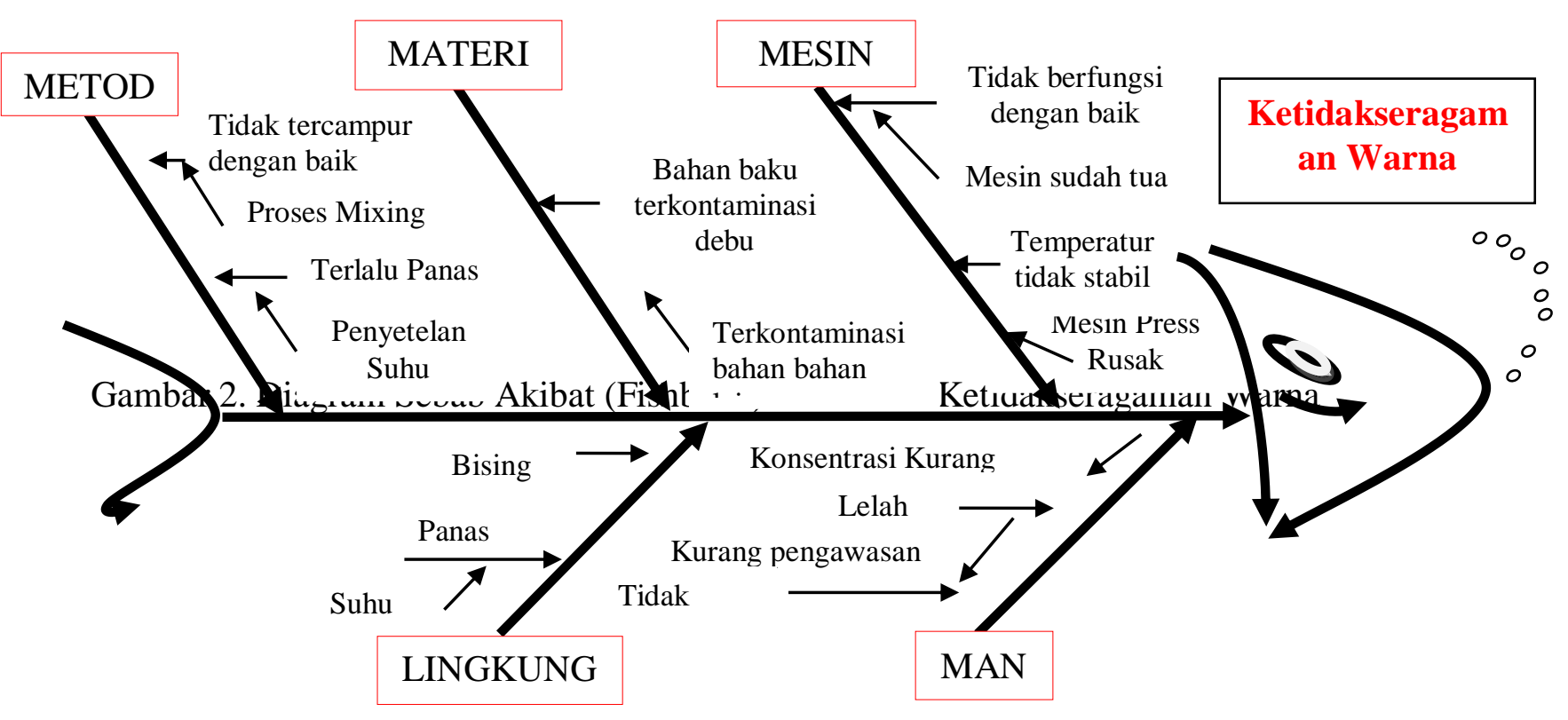

Kegiatan Perbaikan

Untuk menanggulangi cacat ketidakseragaman warna, maka kegiatan perbaikan yang dilaksanakan adalah sebagai berikut:

Tabel 7 Kegiatan Perbaikan Kecacatan Ketidakseragaman Warna Pada Pakan Ternak

\begin{tabular}{|c|l|l|}
\hline Faktor & \multicolumn{1}{|c|}{ Penyebab } & \multicolumn{1}{c|}{ Cara Penanggulangan } \\
\hline Mesin/alat & $\begin{array}{l}\text { - Mesin Press Rusak } \\
\text { - Mesin sudah tua }\end{array}$ & $\begin{array}{l}\text { Melakukan pemeliharaan yang baik dan } \\
\text { rutin serta meregenerasi mesin-mesin } \\
\text { yang sudah rusak. }\end{array}$ \\
\hline Material/bahan & $\begin{array}{l}\text { Terkontaminasi bahan } \\
\text { bahan lain }\end{array}$ & $\begin{array}{l}\text { Mengecek bahan sebelum dimasukkan ke } \\
\text { mesin proses }\end{array}$ \\
\hline Metode/cara & $\begin{array}{l}\text { - Penyetelan Suhu } \\
\text { - Proses Mixing }\end{array}$ & $\begin{array}{l}\text { Memberikan peringatan pada Pekerja } \\
\text { untuk teliti pada saat penyetelan } \\
\text { sehingga suhu dan proses mixing stabil }\end{array}$ \\
\hline Manusia/pekerja & $\begin{array}{l}\text { Memberikan peringatan kepada pekerja } \\
\text { apabila melakukan } \\
\text { sertamemberikan sanksi kepada pekerja } \\
\text { yang tidak teliti untuk menghindari } \\
\text { kegagalan yang mungkin terjadi } \\
\text { dikemudian hari }\end{array}$ \\
\hline Lingkungan & - Pekerja tidak teliti \\
\hline
\end{tabular}


yang disebabkan oleh mesin dan cuaca misalnya dengan menambah kipas angina

Sedangkan untuk mengurangi kecacatan karung sobek pada pakan ternak brider, rencana perbaikan yang digunakan yaitu:

Tabel 8 Kegiatan Perbaikan Kecacatan Karung Sobek Pada Pakan Ternak

\begin{tabular}{|c|l|l|}
\hline \multicolumn{1}{|c|}{ Faktor } & \multicolumn{1}{|c|}{ Penyebab } & \multicolumn{1}{c|}{ Cara Penanggulangan } \\
\hline Mesin/alat & Mesin jahit rusak & $\begin{array}{l}\text { Melakukan pemeliharaan yang baik } \\
\text { dan rutin serta meregenerasi mesin- } \\
\text { mesin yang sudah rusak. }\end{array}$ \\
\hline Material/bahan & $\begin{array}{l}\text { Kualitas sobek dari } \\
\text { pabrik }\end{array}$ & $\begin{array}{l}\text { Pengadaan bahan baku dilakukan } \\
\text { sortir dan dipilih amat teliti dengan } \\
\text { menetapkan sumber yang dipercaya }\end{array}$ \\
\hline Metode/cara & $\begin{array}{l}\text { Posisi karung pada saat } \\
\text { jatuh dari rel tidak tepat }\end{array}$ & $\begin{array}{l}\text { Memberikan peringatan kepada } \\
\text { pekerja agar memperbaiki posisi } \\
\text { karung }\end{array}$ \\
\hline Manusia/pekerja & $\begin{array}{l}\text { Ketidak hati-hatian } \\
\text { pada pekerja }\end{array}$ & $\begin{array}{l}\text { Memberikan sanksi kepada pekerja } \\
\text { yang tidak teliti untuk menghindari } \\
\text { kegagalan yang mungkin terjadi } \\
\text { dikemudian hari. }\end{array}$ \\
\hline Lingkungan & Karung tersangkut & \begin{tabular}{l} 
Mensterilkan area pengangkutan \\
\hline
\end{tabular} \\
\hline
\end{tabular}

\section{Hasil Pelaksanaan Perbaikan}

Hasil Perbaikan

Tabel 9 Data Olahan Jenis Kecacatan Setelah Perbaikan

\begin{tabular}{|c|c|c|c|c|c|}
\hline \multirow{2}{*}{ No } & \multirow{2}{*}{$\begin{array}{c}\text { Tanggal } \\
(\text { Juli 2013) }\end{array}$} & \multirow{2}{*}{$\begin{array}{c}\text { Hasil } \\
\text { Produksi }\end{array}$} & \multicolumn{2}{|c|}{ Jenis Cacat } & \multirow{2}{*}{ Total } \\
\cline { 4 - 5 } & & & $\begin{array}{c}\text { Karung } \\
\text { Sobek }\end{array}$ & $\begin{array}{c}\text { Ketidakseragaman } \\
\text { Warna }\end{array}$ & \\
\hline 1 & 1 & 560 & 3 & 4 & 7 \\
\hline 2 & 3 & 580 & 6 & 3 & 9 \\
\hline 3 & 5 & 580 & 5 & 5 & 10 \\
\hline 4 & 8 & 610 & 4 & 0 & 4 \\
\hline 5 & 10 & 587 & 8 & 9 & 17 \\
\hline 6 & 12 & 550 & 11 & 2 & 11 \\
\hline 7 & 15 & 560 & 0 & 15 & 21 \\
\hline 8 & 17 & 600 & 4 & 7 & 19 \\
\hline 9 & 19 & 576 & 7 & 14 & 13 \\
\hline 10 & 22 & 590 & 9 & 10 & 13 \\
\hline
\end{tabular}


Tabel 10 Populasi data setelah perbaikan dapat dibuatkan grafik pengendali dengan control chart adalah sebagai berikut :

\begin{tabular}{|c|c|c|c|c|}
\hline No. & $\begin{array}{c}\text { Tanggal } \\
(\text { Juli 2013) }\end{array}$ & $\begin{array}{c}\text { Jumlah } \\
\text { Frekuensi } \\
\text { (Karung) }\end{array}$ & $\begin{array}{c}\text { Proporsi } \\
\text { Cacat }\end{array}$ & $\begin{array}{c}\text { Presentase } \\
\text { Cacat } \\
(\%)\end{array}$ \\
\hline 1 & 1 & 7 & 0.0125 & 1.25 \\
\hline 2 & 3 & 9 & 0.015517 & 1.551724 \\
\hline 3 & 5 & 10 & 0.017241 & 1.724138 \\
\hline 4 & 8 & 4 & 0.006557 & 0.655738 \\
\hline 5 & 10 & 17 & 0.028961 & 2.896082 \\
\hline 6 & 12 & 13 & 0.023636 & 2.363636 \\
\hline 7 & 15 & 15 & 0.026786 & 2.678571 \\
\hline 8 & 17 & 11 & 0.018333 & 1.833333 \\
\hline 9 & 19 & 21 & 0.036458 & 3.645833 \\
\hline 10 & 22 & 19 & 0.032203 & 3.220339 \\
\hline & Jumlah & 126 & 0.21819 & 21.8194 \\
\hline & Rata-rata & 12,6 & 0.021819 & 2.181939 \\
\hline
\end{tabular}

Berdasarkan data dari hasil perhitungan dalam tabel 10 kita akan menghitung simpangan baku untuk peta control $\mathrm{P}$, yaitu :

- Apabila menggunakan nilai proporsi simpangan baku dihitung sebagai berikut :

$$
\begin{aligned}
& \mathrm{sp}=\sqrt{\frac{p(1-p)}{n}} \\
& \mathrm{sp}=\sqrt{\frac{0.021819(1-0.021819)}{126}} \\
& \mathrm{sp}=\sqrt{\frac{0,021343}{126}} \\
& \mathrm{sp}=\sqrt{0,000169} \\
& \mathrm{sp}=0,013
\end{aligned}
$$

- Dan apabila kita menggunakan persentase, maka simpangan baku dihitung sebagai berikut :

$$
\mathrm{sp}=\sqrt{\frac{p(100-p)}{n}}
$$




$$
\begin{aligned}
\mathrm{sp} & =\sqrt{\frac{2.181939(100-2.181939)}{126}} \\
\mathrm{sp} & =\sqrt{\frac{213,4331}{126}} \\
\mathrm{sp} & =\sqrt{1,693913} \\
\mathrm{sp} & =1,3 \%
\end{aligned}
$$

Selanjutnya menentukan batas-batas control 3-sigma sebagai berikut :

- Peta control (batas-batas control 3-sigma) untuk nilai proporsi

$C L \quad=\bar{P}=0.021819$

$\mathrm{UCL}=\bar{P}+3 . \mathrm{sp}$

$=0.021819+3(0,013)$

$=0.060819$

$\mathrm{LCL}=\bar{P}-3 . \mathrm{sp}$ $=0.021819+3(0.013)$

- Peta control P (batas-batas control 3-sigma) untuk menilai persentase :

$\mathrm{CL}=\bar{P}=2,18 \%$

$\mathrm{UCL} \quad=\bar{P}+3 . \mathrm{sp}$

$=2,18 \%+3(1,3 \%)$

$=6,08 \%$

LCL $\quad=\bar{P}-3 . \mathrm{sp}$

$$
\begin{aligned}
& =2,18 \%-3(1,3 \%) \\
& =-1,71 \%
\end{aligned}
$$

- Pengolahan dengan indeks kapasitas (Cp)

Pengolahan ini digunakan untuk mengetahui kapabilitas suatu produk apakah produk itu baik atau jelek. Dari analisa perhitungan peta control $\mathrm{P}$ maka didapatkan Cp sebagai berikut :

Indeks kapasitas proses $(\mathrm{Cp})$ pada peta control untuk nilai proporsi :

$$
\mathrm{Cp}=\frac{U C L-L C L}{6.5} \rightarrow \mathrm{s}=1-\mathrm{P}
$$

Dimana: $\mathrm{Cp} \quad=$ indeks kapasitas

$\mathrm{P} \quad=$ rata-rata kecacatan

$\mathrm{UCL}=$ garis kendali atas

$\mathrm{LCL}=$ garis kendali bawah

6.s = enam simpangan baku

Jadi :

$$
\begin{aligned}
\mathrm{Cp} & =\frac{0,060819-(-0,01718)}{6(0,9781)} \\
& =\frac{0,078}{5,8690} \\
& =0,01329
\end{aligned}
$$

Indeks kapasitas proses $(\mathrm{Cp})$ pada peta control untuk nilai persentase : 


$$
\begin{aligned}
\mathrm{Cp} & =\frac{U C L-L C L}{6 . S} \rightarrow \mathrm{s}=100 \%-\mathrm{P} \\
\mathrm{Cp} & =\frac{6,082 \%-(-1,72) \%}{6(97.81 \%)} \\
& =\frac{7.8 \%}{586,90 \%} \\
& =0,01329 \%
\end{aligned}
$$

\section{Kesimpulan}

Berdasarkan hasil analisa diperoleh beberapa kesimpulan sebagai berikut :

Dari hasil analisa didapatkan faktor penyebab terjadinya produk pakan ternak brider yang cacat ketidakseragam warna dan karung yang sobek disebabkan oleh ketidaktelitian para pekerja dan kedisiplinan yang kurang serta pemeliharaan dan perawatan mesin yang belum maksimal.

1. Dari hasil perbaikan maka didapatkan tingkat kerusakan produk pakan ternak brider dari $2,43 \%$ turun menjadi 2,18\%, sehingga dapat meminimalkan tingkat kerusakan produk pakan ternak brider yaitu dengan memberikan motivasi kepada pekerja agar lebih teliti dan bertanggung jawab dalam melaksanakan tugasnya, penerapan metode kerja kepada operator/pekerja dan perawatan alatalat produksi.

2. Dari semua instrumen pengendalian kualitas yang telah digunakan, maka dapat kami simpulkan bahwa instrument yang paling tepat dan memberikan kegunaan serta dapat menghasilkan kualitas yang optimal adalah dengan menggunakan metode fishbone chart.

\section{Daftar Pustaka}

Assauri, Sofjan. 2004. Manajemen Produksi dan Operasi. Jakarta: Lembaga Fakultas Ekonomi UI.

Besterfield, Dale H, Quality Control, Fourth Edition, New Jersey: Prentice-Hall Inc, 1994

Kuswandi., Mutiara, E. 2004. Delapan Langkah Dan Tujuh Alat Statistik Peningkatan Mutu Berbasis Komputer. PT. Elex Media Komputindo: Jakarta.

Montgomery, Douglas C., (2001). Design and analysis of experiments, 5th edition, John Wiley \& Sons, Inc.

Russell, Roberta S. and Bernard W. Taylor III, 2005, Operations Management, PrenticeHall International, Inc., Upper Saddle River, New Jersey 